\title{
Quito's Archaeological Heritage Protection: The "Delimitación de Áreas Arqueológicas del Bloque Quito" Project as a Case of Study
}

\author{
Carlos Montalvo1, Andres Mosquera 2 , Eric Dyrdahl ${ }^{3}$, Valeria \\ Rivera $^{4}$, Santiago Solines ${ }^{5}$, Maria Gracia Riofrío ${ }^{5}$ \& Gabriela Granja ${ }^{5}$ \\ ${ }^{1}$ Instituto Panamericano de Arqueología e Historia, Sección Ecuador \\ ${ }^{2}$ Instituto Metropolitano de Patrimonio - Quito \\ ${ }^{3}$ Pontificia Universidad Católica del Ecuador - Quito \\ ${ }^{4}$ Independent Researcher \\ ${ }^{5}$ Solines \& Asociados
}

\begin{abstract}
This work aims to outline and discuss the challenges and issues related to the protection of archaeological sites in urban contexts from an interdisciplinary approach, focusing on the collaboration and regulation between academia, consultants, local government offices and citizens. To achieve this objective, a team formed by archaeologists, geographers, and lawyers, coordinated and financed by a local government office (Municipality of Quito), was formed to develop tools to incorporate in the city's cadastral map and draft specific legislation to regulate the land use in archaeologically sensitive areas. GIS (geographic information system) tools were applied to collect the geographical data (generation of an archaeological map) of the sites and compared with Quito's cadastral data. The drafted law also pretends to raise awareness of landowners, construction companies, and the broader community, providing them with information about the properties located in archaeologically sensitive areas and establishing channels of dialogue between the relevant parties that will lead to the development of research projects in sensitive areas prior to their destruction.
\end{abstract}

Keywords: GIS, Site protection, Quito, Archaeology

\section{Introduction}

Since its formulation (McGimsey 1972) the concepts of public archaeology have evolved over time and come to incorporate notions that vary around the world. As stated by

CONTACT: Carlos Montalvo, cemontalvop@hotmail.com; Andres Mosquera, andres.mosquera@quito.gob.ec, andresrofacale@hotmail.com; Eric Dyrdahl, edyrdahl884@puce.edu.ec; Valeria Rivera, avaleria.rivera@gmail.com; Santiago Solines, ssolines@solines.ec; Maria Gracia Riofrio, mriofrio@solines.ec; Gabriela Granja, ggranja@solines.ec 
Matsuda and Okamura (2011), this discipline includes communication and relation of archeology with the public or publics (people) and how archaeology interacts with the public sphere, or how the public receive, interpret, and relate with the discipline in real life outside of academic constructs. This relation intertwines three main subjects: archaeology as a discipline (academic researchers and CRM contractors), the political sphere and its duty to develop policies and legislation that protect and preserve cultural heritage (government), and the citizenship as a public that the receives and consumes archeological information (people) (Richardson \& Almansa-Sánchez 2015: 1-2).

\section{Public archaeology in Ecuador}

In Ecuador, the idea of public archaeology can be linked to the CRM concept developed in the United States as well as the struggle with problems linked to the development of infrastructure (Gnecco \& Schmidt: 2015; Richardson \& Almansa-Sánchez 2015). Since the late 1980's, driven by the petroleum boom, CRM projects mainly have been related to the development of infrastructure in the Amazon region. Sadly, in most of cases, the CRM activities carried out (including today) are seen as simply a requisite to obtain building permits and initiatives to rescue the history of the affected areas have not evolved much beyond involving the affected communities in research or sharing the recovered information with the public (Delgado-Espinoza 2008: 149; Valdez 2010: 16-19).

Focusing on the relation between citizenship and archaeology, it is important to mention that the organic law of culture delineates the role of the state in cultural matters since 2016, and includes archeological heritage. As the law refers in more general terms to cultural heritage, it is clear stating that

"People, communities, communes, nationalities, collective and cultural organizations have the right to build and maintain their own cultural and aesthetic identities, to decide about the enrollment in a single or multiple cultural communities and to express this choice. No one will be object of discrimination or retaliation by choosing to identify themself, express or relinquish to one or many cultural communities." (Ley Orgánica de Cultura 2016: art.5).

We can underline the role of the state as a "guarantor" of the cultural rights of the people to identify as part of one or several cultural groups and as protector and tutor of the cultural heritage.

Even if the law covers all aspects of culture and heritage, it is important to further discuss how this legislation has resulted in repercussions for the archaeological discipline, especially with regard to how non-experts relate with archaeology. As stated by Valdez, in the eyes of the public (indigenous or mestizo), archeological remains (were) are seen as an economic resource in the best of the cases, and any cultural or identity links with ancient populations are almost completely broken. Sacred values and ancient knowledge do not exist anymore, and the population (even indigenous) does not associate themselves with them save for a few exceptions (Valdez 2008: 20). In this framework, the culture law is an effort (even if for now it only exists on paper) to partially recognize and encourage the generation of these values, and regulate the relation between people, state, and heritage as part of culture. 


\section{Public Archaeology in Quito}

Quito has a unique relation with Ecuador's cultural heritage: public conscience of its importance developed with the declaration that Quito's colonial historical center is a UNESCO World Heritage site in 1978. After this declaration, city and country authorities began to pay more attention to protecting the area, and the local population started to find an identity in it. In archaeological matters, areas now inside the city were explored during the early twentieth century (Jijón y Caamaño 1952; Jijón y Caamaño \& Larrea 1918; Uhle 1926). Later, this research continued with the interventions on behalf of the Banco Central del Ecuador (Villalba 1996; 1988), Pontificia Universidad Católica del Ecuador (Echeverria 1977; Porras 1982), Instituto Nacional de Patrimonio Cultural (Doyon 1988), and foreign researchers (Bray 1990; 2003, Buys 1987; 1994, Lippi 2004).

Since the 1990's, the Fondo de Salvamento (FONSAL) (now Instituto Metropolitano de Patrimonio (IMP), a municipality dependency created to technically manage the cultural heritage of the city (before the 1987 earthquake), has taken on the task of archaeological research and protection. Since then, with support from the Central Bank of Ecuador and Instituto Nacional de Patrimonio Cultural (INPC) Ecuador, archaeological research investigation has been undertaken in areas of the city under pressure from urban expansion. As part of the results of these efforts, the city manages three site-museums and establishes planned research objectives of archaeologically sensitive areas in the city limits. Since the late 1990's/early 2000's, FONSAL/IMP has formulated long-term planification to study, register, and preserve the archaeological heritage of the city. The rapid growth of Quito, pushed in part by the increasing price of petroleum, led to the development of major infrastructure projects with massive public funds that in part were allocated to conduct preventative archaeological projects under the control of FONSAL/IMP (for Nuevo Aeropuerto: see Aguilera 2007; 2008; 2009. For Metro de Quito see: Sanchez 2020. For Ciudad Bicentenario - Tajamar: see Domínguez 2008). The modality chosen for these projects was to contract hire archaeologists as contractors to develop consultancies under the supervision of IMP archaeologists.

Utilizing this same format, projects with research objectives not necessarily related with infrastructure development also were conducted. The main goal was to obtain additional information about the occupations of selected sites as part of the efforts to responsibly conserve and research the archaeology of Quito and increase the general knowledge about archaeology in the urban area. Rumipamba (Constantine 2013), Rancho Bajo (Ugalde 2019), and Tagshima (Ugalde \& Dyrdahl 2020) are examples of sites that have been investigated in this manner and have enhanced our understanding of some of the earliest and latest prehispanic occupations in Quito.

Even if Quito is by far the most advanced city in Ecuador with regard to its management of archaeological and cultural heritage, this does not mean that the local population even know or care about the archaeological evidence located under their feet. The public perception is that archaeological remains, if located on their properties, are a nuisance that can lead to expropriation, so private proprietors rarely report findings. This situation has resulted in a dearth of information about the archaeological sites in the urban area, even if the heritage law and regulation (Ley de Cultura and Reglamento General de la Ley de Patrimonio cultura, both of 1984 - now abolished by the approval of the organic culture law of 2016see Echeverria 2009) specified that archaeological explorations were mandatory in projects 
that resulted in the movement of soil, this rule was tacitly considered to be applicable only to infrastructure operations and not in private civil building.

\section{The Delimitación de Áreas Arqueológicas del Bloque Quito}

The project outlined in this article - the Delimitación de Areas Arqueologicas del Bloque Quito was proposed by the IMP as an effort to develop a model of management and control for the archaeological heritage in all the administrative territories of Quito (i.e. urban and rural). In 2003 and 2004, extensive survey campaigns were conducted as preventive archaeology projects in all the urban and rural areas under the domain of the municipality. The Atlas Arqueológico de Quito (FONSAL 2009) was published in 2009, consolidating all of the information collected from this fieldwork (Domínguez 2002; Domínguez et al. 2003; Villalba 2004; Tamayo 2005). The survey of the entire administrative district was divided into three books based on geographical criteria, as Quito's administrative district includes a diverse array of landscapes and ecological areas with altitudes ranging from 1500 masl to 4500 masl.

This more recent project was focused on surveying two of the zones delimited by the atlas (Fig. 1): the urban area of Quito, including Cumbaya and Los Chillos Valley, and the rural zone of Pintag. The main objectives were (1) the verification of the current state of conservation of the previously documented sites, (2) the actualization and collection of new high precision geographical data with the help of a GNSS receiver, (3) the modification of the geographical data from a single point with a coordinate to a multipoint coordinate that facilitates the creation of delimited areas that can be tied into the city's cadastral map in order to create a system of archaeological sensibility information, and (4) the elaboration of a draft of a new city law, including all of the collected information and developed tools, to regulate the protection of the archaeological sites found within the city's boundaries (IMP 2020; Montalvo et al. 2021). 


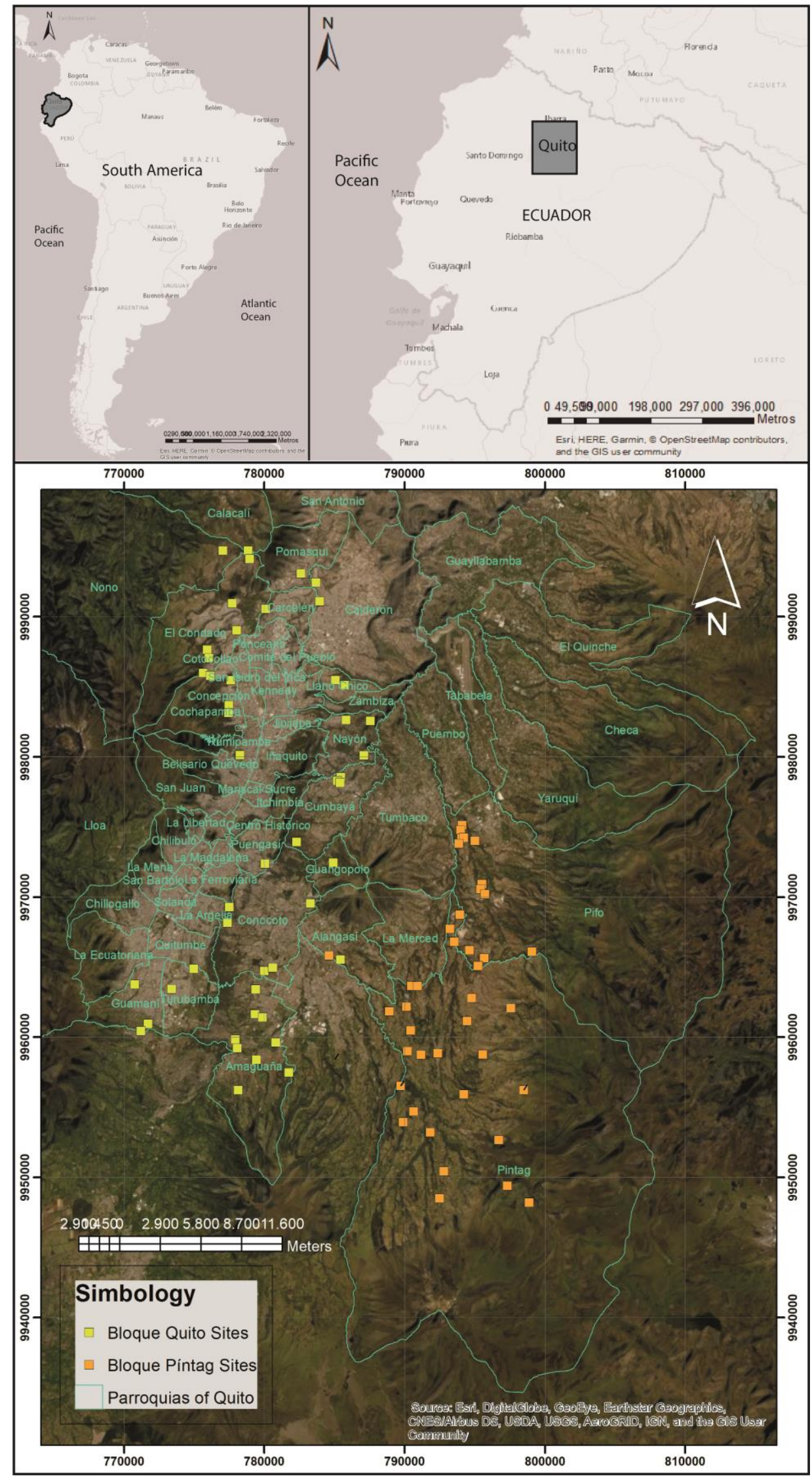

Figure 1. Map of the project area (elaborated by Valeria Rivera and Carlos Montalvo. Credits by base cartography to ESRI). 


\section{Methodology}

The project methodology can be outlined in four steps: 1) data collection, 2) SIG management, 3) crossing data of generated layers and cartography generation, and 4) the elaboration of ordinance draft. Each step involved a series of actions that will be described in detail in the following paragraphs (Fig. 2).

For data collection, field verification and the collection of new geographical data was critical. This step mainly relied on non-invasive pedestrian surveys (Montalvo \& Dyrdahl 2017). Each visit began with locating the original coordinate registered in the Archaeology Atlas (FONSAL 2009), and was followed by examination of any exposed archaeological features and materials as well as the verification of the degree of affectation caused by urban expansion. After identifying and delimiting the archaeologically sensitive area, new geographical data was collected. During each visit, all the gathered information was stored in forms of multiple formats (paper and digital), with the standard information recorded for each site including administrative, archaeological, geographical, photographical, cartographical, and bibliographical data. The geographical data was registered using WGS84/UTM formats (17S meridian for the geographical area of interest) in .txt or Excel files to later be projected using GIS software.

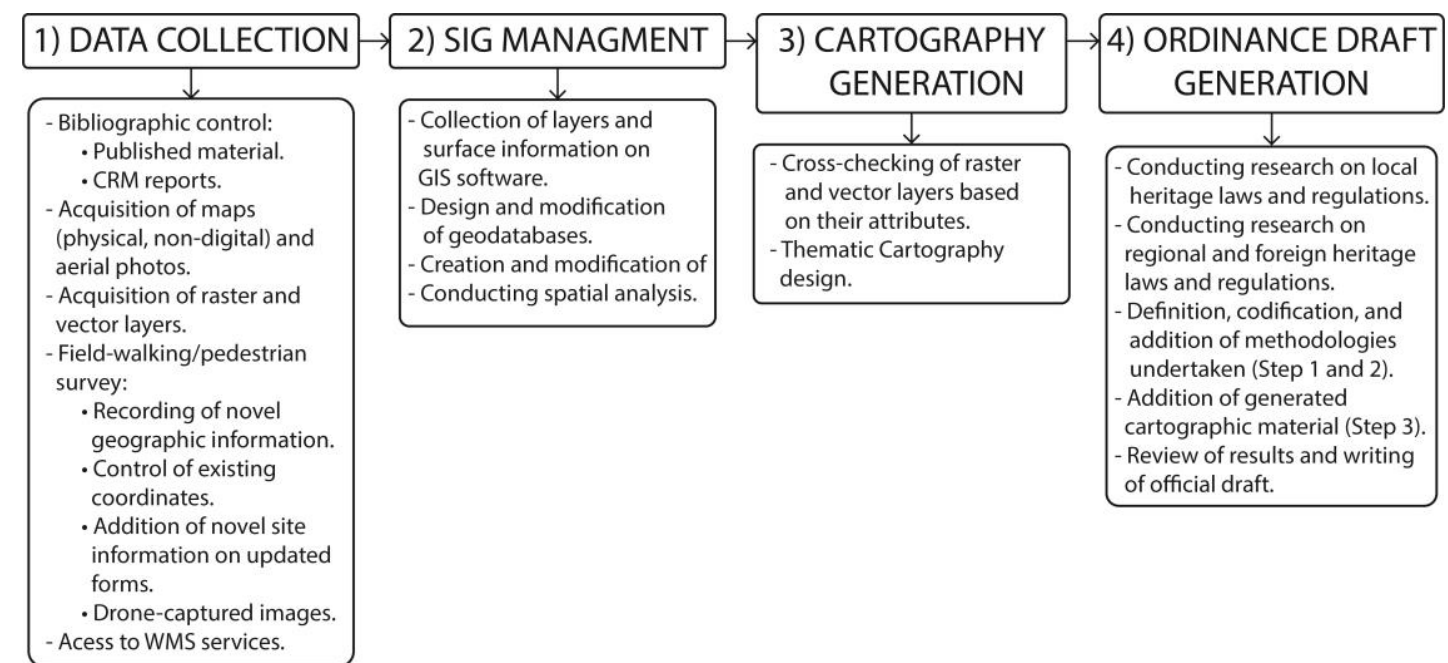

Figure 2. Workflow applied on the project (elaborated by Carlos Montalvo).

Data collection also included the obtention of historical satellite imagery and digital terrain model (DTM) shapefiles (SIGTIERRAS project), updated satellite imagery (IGM web services), political territory and cadaster polygonal shapefiles, and original point shapefiles with the published coordinates for the sites (FONSAL 2009). For areas lacking information, without updated imagery or DTM, or where greater resolution was required, drone surveys were carried out to generate ortho-photos. Drone-produced orthophotography and digital models were refined with control points to reduce errors and improve accuracy (Montalvo et al. 2020).

A GIS software was used to organize all of the collected information. The management of this information included the storage of all of the data collected during fieldwork, bibliographical information transformed into shapefiles, governmental office web services (WMS), and shapefiles. The organization of the entire suite of data was fundamental to 
the organization structure and analysis development that helped us to generate the cadaster-sensibility tool. Once in GIS, the geographical data was mainly used to create the site polygons and define areas of interest. As part of this process, we used three main types of information gathered during the previous phase of research: geographical element delimitation, visual inspection of remains, and bibliographical information. We also used one spatial analysis tool for the development of buffer zones (Fig. 3).

It is important to specify that this project generated two distinct types of site registries depending on the type of evidence encountered in the field. The first type is related to monumental sites such as mounds, fortresses, and other monumental structures, as well as sites where previous research has resulted in important scientific information (e.g. fortresses of Ingaloma and Añaro as well as mounds of La Merced for the former, sites such as La Florida and Rumipamba for the latter). The second type of registry was created for sites that are non-monumental and have not been investigated in detail. For the sites in the first registry, a rigid area of protection was established, while for the sites in the second registry a sensibility categorization was created to promote that the sites are researched prior to their destruction due to construction or other modern activities.

Once the site polygons were generated, this information was crossed with the cadastral map of Quito. As mentioned previously, the areas of interest are divided into urban and rural areas, so, depending on this divide, it was possible to adapt to specific circumstances found in the two types of spaces. In particular, this was important to address the issue that in urban areas there frequently are many landowners for a particular archaeological site while more commonly in rural areas the entire site is on a parcel of land owned by a single individual or entity.

In the case of the sensibility polygons, a tiered categorization was developed: red for high sensibility, yellow for medium sensibility, green for low sensibility, and light blue for null sensibility or no data. The implications of this system will be discussed later. The highest sensibilities were given to properties located within the boundaries of the archaeological polygons. Medium sensibility was tied to two circumstances: 1) properties located inside the archaeological polygons with buildings that partially alter the surface and 2) properties in the immediate vicinity of the known archaeological area. Low sensibility is also related to two distinct possibilities: 1) properties within the established polygons where buildings alter the majority of the surface and 2) in the vicinity of properties with medium sensibility related to a nearby archaeological site. Finally, null sensibility was given to properties inside archaeological polygons where the entire surface is covered by construction, areas where information is not available, and areas far from archaeological sites (Fig. 4).

One of the products created via the crossing of data was a cartographic layer of archaeological sensibility. This layer, combined with updated satellite imagery, allowed us to clearly identify the parcels of lands that lack development, are partially occupied by construction, and those totally covered by buildings (following, in part, the methodology described in Montalvo 2020). This information was crucial in order to apply the sensibility characterization described previously.

All of the information and generated cartography products were instrumental in the elaboration of the draft for the proposed law. This component of the work was undertaken by an interdisciplinary team including archaeologists, geographers and lawyers. The legal team proceeded to cross-check national, regional and international legislation on 
the matter in order to see what experiences can suit or be adapted to the situation of Quito. Using as a foundation Ecuador's Constitution, the Organic Law of culture, and the municipality competences laws (COOTAD), a specific regulation was produced. Also, the INPC proposal of regulation and management of archaeological areas was taken into consideration, even if it was still under development (INPC 2020).

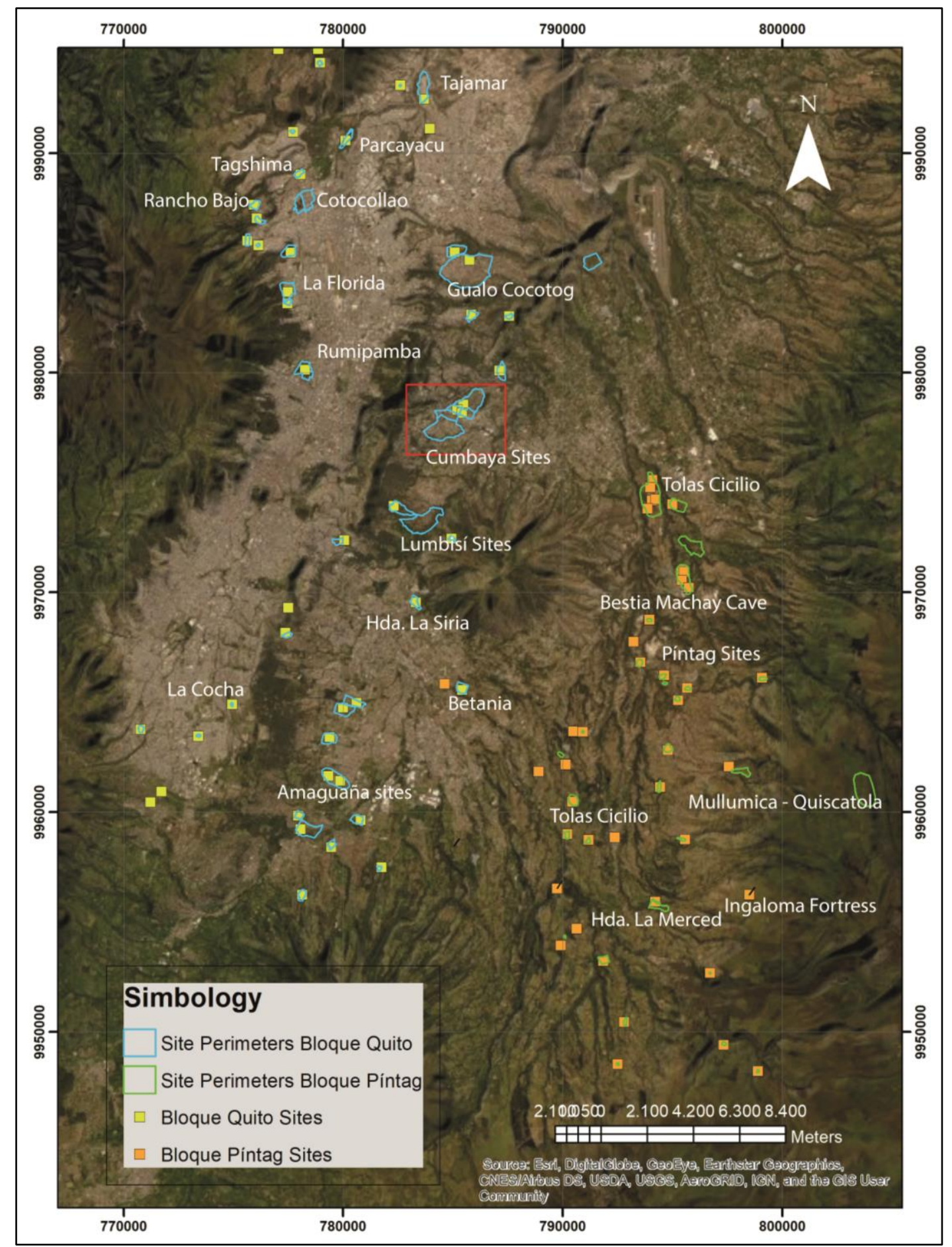

Figure 3. Map with site perimeters: in red Cumbaya sites (elaborated by Valeria Rivera and Carlos Montalvo. Credits by base cartography to ESRI). 


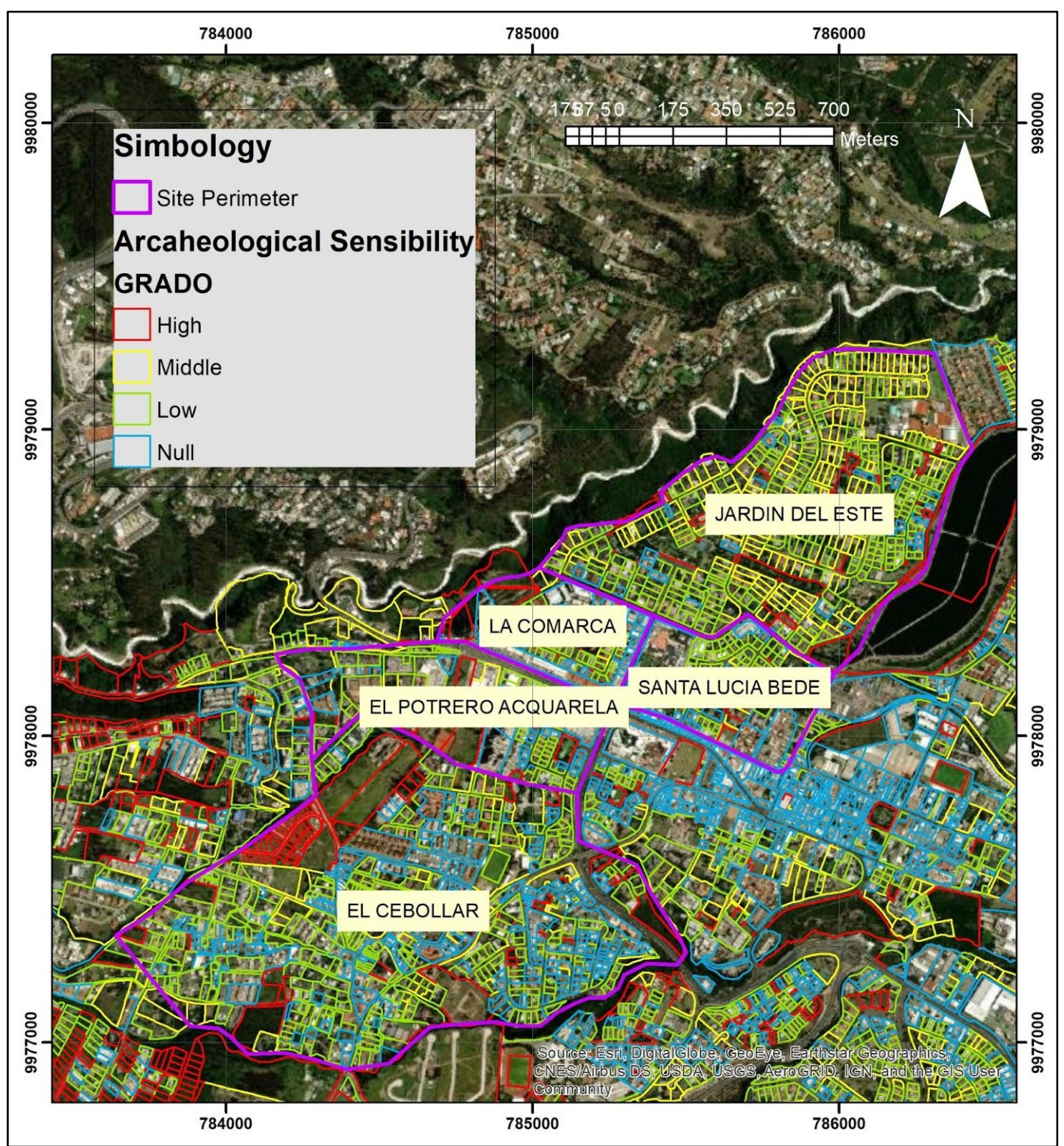

Figure 4. Cadaster layer with sensibility symbology: detail of Cumbaya sites (Elaborated by Valeria Rivera and Carlos Montalvo. Credits by base cartography to ESRI).

\section{Discussion}

The cadaster tool as an instrument of protection, the legal codifications, and the involved parties

From the point of view of public archaeology, the question that must be posed to all parties is: What will be the result, or the consequences, of the application of a specific ordinance to protect archaeological sites? We will try to analyze the possible answers and responses to this question, taking into consideration the different interests at stake. We will start with the local government agencies, continue with the landowners and building companies, and conclude with the academic archaeology point of view.

\section{The municipality offices of heritage and planification}

The main municipality offices involved in this issue are the heritage office, the IMP, and the Secretaria del Territorio Hábitat y Vivienda (Planification Office). The planification 
department is the branch of the municipality in charge of elaborating and maintaining the cadastral map. As a result, this is the entity that establishes the permitted land uses inside the city limits and elaborates policies related to city planification and development. Meanwhile, the IMP is the city's institute or office dedicated to the study, research, restoration, and protection of the historical, archaeological, and non-material heritage of the city.

According to local regulations, the IMP is responsible for defining and evaluating the archaeologically sensitive areas that require protection. This means it is responsible for gathering the technical information about spaces and areas with the presence of archaeological sites (Código Municipal001). In a second step, Quito’s municipality approves the protection areas by applying planification instruments and city council resolutions to protect the archaeological heritage of the city. Within the planification instruments, the main avenues available to promote the protection of archaeological sites are the Plan Metropolitano de Ordenamiento Territorial - PMDOT (Metropolitan Plan of Territory Arrangement) and the Plan de Uso y Gestión del Suelo - PUGS (Land Use and Management Plan ). The former contains the guidelines, policies, and objectives relevant to the strategic planification of the municipality's territory (Plan Metropolitano de Desarrollo y Ordenamiento Territorial 2015 - 2025). The latter includes among its themes the regulation of land use in both rural and urban areas.

Planification tools have been created to guide the institutional field of action and decisionmaking process within Quito. The inclusion of cultural heritage information within these tools will make it possible to articulate with other elements that are considered in the planification of land use in the city. This project has generated geospatial information of the archaeological sites with the objective of promoting this articulation, and as a result guaranteeing the protection of the archaeological sites in Quito in accordance with local and national regulations.

The objectives outlined above potentially can enter into conflict with urban development in areas that have high archaeological sensibility and are under pressure by urban expansion. To mitigate possible issues in this regard, a cross reference of the archaeological areas and cadastral map was undertaken, developing a technical tool that can be used by both the planification office and IMP in order to create easier access to detailed information about the possible affectations of each property within a particular area of archaeological sensibility.

The IMP oversees the continual update of the archaeological map of Quito: one of its main responsibilities in this area is the generation of geospatial information related to the archaeological sites. Any activities related to the management of the archaeological heritage of the city are coordinated with the INPC, as established by the Ley Orgánica de Cultura (Organic Law of Culture). The INPC is the main authority in charge of supervising archaeological research and site delimitation for its management.

Active collaboration between both offices can lead to effective protection of the archaeological heritage of the city by articulating research and guardianship of the sites. The IMP can organize and coordinate specific interventions, promote research, and push for protective measures. The planification office can take this information and include it in land-use planification to help mitigate possible damage to archaeological sites. 


\section{Landowners and building companies}

"... asi que Ud. es el que anda jorobando a la gente."”

(Comment by M. Navarro, a landowner dealing with an archeological site located in his property).

Many landowners did not know, or bother to learn, that there are archaeological sites on their properties. The first reaction to the presence of archaeologists (which is even worse if the archaeologist is as part of a municipality project) is the fear of expropriation. In most cases, by ignorance or fear, the archaeological sites are destroyed.

As stated before, most landowners do not know or have access to tools that would help them learn about the presence of archaeological sites on their properties and in surrounding areas. One of their first comments frequently is that the planification office and cadaster did not register any kind of information about the presence of archaeological or historical remains, so they do not know how to act when remains are identified or how to handle an inspection of archaeological evidence. The great majority are surprised to learn about archaeological evidence on their properties, some are annoyed, and a small group will be curious. In one instance, we even had the landowner call the police to stop the inspection.

With regard to construction companies, there are some areas of the city currently undergoing major urban expansion (i.e. Cumbaya, Los Chillos and Nayon Valley) with an increasing appreciation of land value and where large building projects are underway. In the case of the Cumbaya valley, almost all of the area presents a high archaeological sensitivity with different sites dating to the Integration (500 - 1500 AD) and Regional Development (400 BC - $500 \mathrm{AD}$ ) periods. In this sense, large projects that do not implement mitigation strategies or undertake research can result in the loss of important archaeological data. Until this project, information regarding archaeological sensibility has not been available when consulting the cadaster and there is not a firm legal requirement for private building projects to undertake research projects prior to land modification (unlike public infrastructure projects). Therefore, until now, most building companies did not take any steps to protect archaeological remains.

The project presented here, with the sensibility tool embedded in the cadaster and the legal proposals regarding the draft of the ordinance, aims to put archaeological information in the hands of landowners and building companies so that it is clear how they must proceed if they are going to undertake construction projects, whether large or small. The goal is not necessarily to stop building and urban development, but rather place considerations related to destruction of archaeological data and the need to conduct salvage research more actively in the decision-making process for building developments. A middle ground must be found where archaeological data and sites are valued, protected, and studied, but on the other hand, construction projects can continue and contribute to Quito's economy.

1 "...so, you are the one that causes people trouble". 


\section{Archaeologists and academics}

In relation to the subject matter, there are four main obligations for archaeologists: 1) promote the correct application of the legislation in order to avoid the destruction of archaeological evidence, 2) maintain high standards in accordance with international procedures and national legislation when undertaking CRM projects, 3) maintain a high ethical standard in their interactions with the broader public as well as colleagues, and 4) share and make public (or publish) the recovered data. Perhaps these obligations are obvious to most, but they cannot be taken for granted as they are not always applied evenly. As certain scholars have discussed on the regional level, contract archaeology has had some problematic characteristics in the last two decades, especially related to the cash flow, political and business interests, pressure from companies and contracts, and archaeologists being abusive with their fees, among others (Gnecco \& Schmidt 2015; Tantaléan \& Gonzales 2017). On the other hand, the IMP of Quito, with its management of research projects with planned objectives since 2017, shows how under the dynamics of CRM this kind of experience can be conducted in a professional manner with high standards.

One of the primary tasks of the archaeological community as a participant in this process is to publicize on every level possible the importance of the archaeological sites found in the city. Collaboration with heritage authorities is fundamental to achieve this goal. Being active, constructively proposing solutions, and building bridges between all the involved parties can be fundamental components of strategies that result in better protection for the archaeological sites.

\section{Legal considerations}

The proposed draft of the law specifies that in the case of properties with high archaeological sensibility, research (survey, excavation, and monitoring of soil movement) is mandatory. Every activity that results in soil displacement has to be supervised, and, depending on the importance of the archaeological evidence, the prohibition of building can be declared. On parcels of land with a medium sensibility, archaeological survey is mandatory, and the supervision of soil movement is recommended in order to avoid the destruction of contexts. Depending on the initial findings, it can be determined that archaeological excavations are required. In the case of land with a low sensibility, an archaeological inspection is mandatory and during this process it will be determined if other actions are needed. Finally, with regard to null sensibility, no action is needed but the contractor or landowner has to report occasional finds in order to evaluate if additional actions are required ${ }^{2}$ (Fig. 5).

The importance of the sensibility zonification tool from a legal point of view is that it helps establish what kinds of actions the public (landowners, building companies and common people), professionals (archaeologists), and city government (IMP) officials must undertake and control. The role of the public is to protect, allow and finance the research in order to protect the relevant archaeological remains and data. Professionals must lend

\footnotetext{
2 The sensibility zonification concepts were developed by Kyra Torres and Fernando Mejía from the INPC in a draft of a regulation to establish archaeological protection zones. This project took these concepts, tested them, and adapted them to Quito's needs.
} 
their knowledge to ethically study the remains and publish the results (most likely under CRM rules). City governments have to coordinate and facilitate the coordination of the works in accordance with the law while also supervising. This organization is fundamental in order to prevent site damage, especially in areas where people frequently build houses without permission of the planification office. In these areas, coordination, cooperation and information sharing with the residents (and their compromise related to protecting the site) are fundamental. In these instances, it is important that the municipality helps with economic solutions to finance any required research.

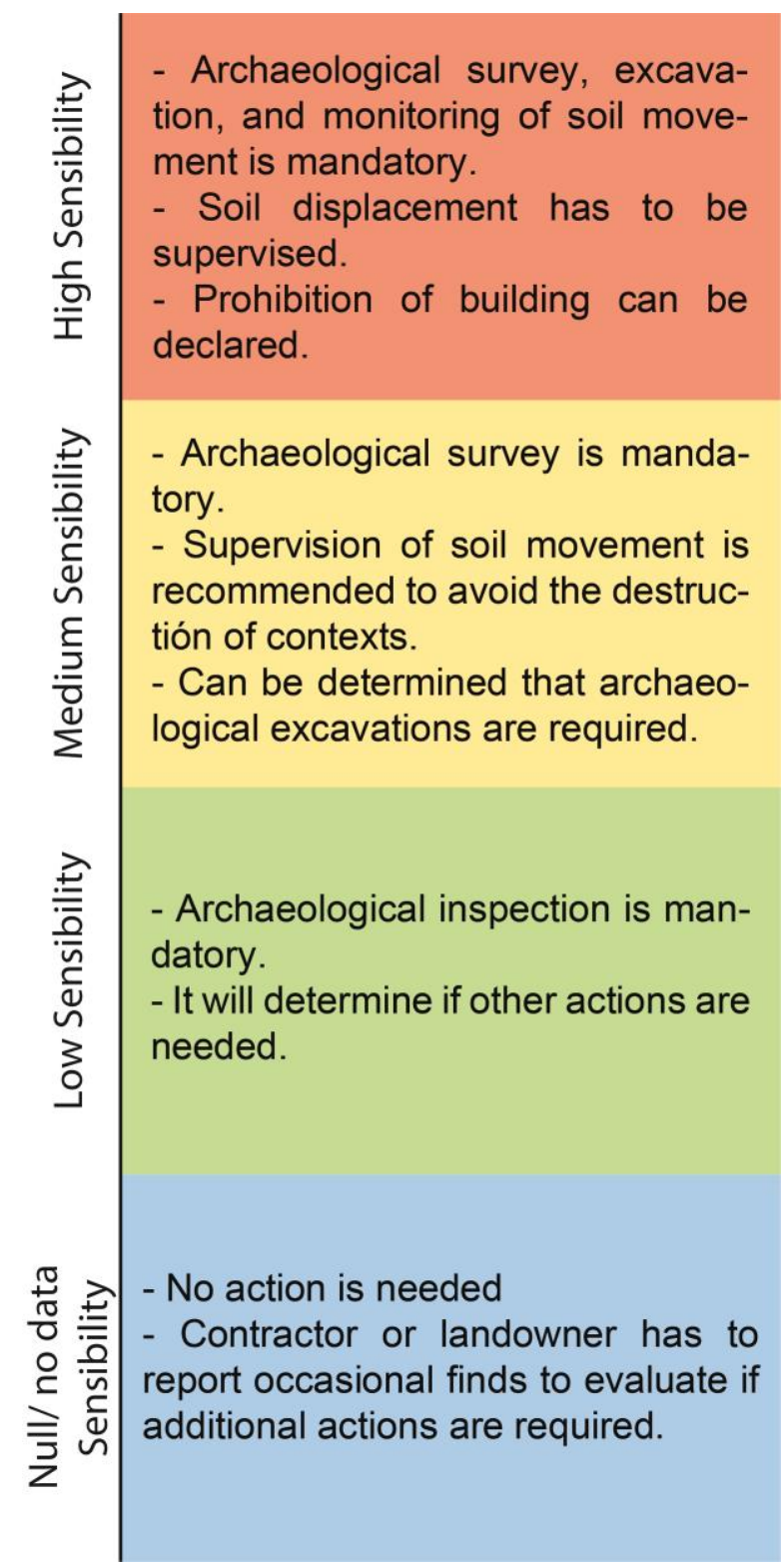

Figure 5. Table with restrictions and actions by sensibility degree (elaborated by Carlos Montalvo).

The cadaster - sensibility tool as an informative tool for the management, research, and public knowledge of archaeological heritage

The inclusion of archaeological information in the cadaster can be a powerful tool to make community members more conscious that there is an archaeological site in the area. Landowners and construction companies will have clear indications regarding how to 
proceed in the case that they want to sell or build on their properties. The municipal offices will be able to channel and promote the necessary actions while also advising members of the public about how to proceed.

Eventually, the objective is that this information can be made available in the future as a geoportal that can be consulted by all citizens. A map is an immediate tool that permits the rapid transmission of information, and now thanks to the high quality satellite imagery and 3D models, it is possible to explore the entire range of geographical areas within Quito. Awareness that their house sits on an archaeological site can help promote its protection or investigation.

\section{South American Context for the zonification}

In some South American countries, a specific paragraph in the heritage law or the regulatory text annex to the main law is present to regulate zonification or archaeological sensibility areas (for Brasil see Instrução Normativa n.001 de 25 de Março de 2015: cap. II, art. 9; for Colombia see Régimen Legal y Lineamientos técnicos de los programas de Arqueología Preventiva en Colombia 2010: Articles 2 and 3; for Ecuador see Ley Orgánica de cultura 2016: Art. 67). These pieces of legislation are directed to regulate urban expansion but mainly focus on infrastructure construction or mining activities that are/were linked to the extraction of raw materials like petroleum and gas in areas with a high biodiversity or archaeological remains sensibility (Tantaleán \& Gonzales 2016: 12-14; Londoño 2016; Gnecco and Schmidt 2015: 693-695). In this context, since the 2000's, in neighboring countries the relevant heritage authorities aimed to develop national archaeological maps to register and administrate this kind of cultural heritage (for Colombian example see Posada-Restrepo \& Duque-Tangarife 2018: 25) and Brazil is the only example that specifically requires shapefiles as products (Instrução Normativa n.001 de 25 de Março de 2015: cap. I, art. 3). A similar effort was undertaken in Ecuador in 2009.

Even if the causes of problems are the same for all of the region, as stated before, the responses vary depending from country to country. A specific tool as developed on this project is not operative in the region. Even so, Colombia and Brazil dispositions about the matter are closer in concept to the proposed zonification of the archaeological remains for Quito.

\section{Conclusions}

Ultimately, even if this effort up to this point only has resulted in the production of a proposal draft of a law for the protection of archaeological sites in Quito that still has to be discussed and reviewed by the city council, the broader project developed a system to collect, update, and manage information related to archaeological sites within Quito using a GIS software. It also developed and defined the attributes to be added to the cadaster in order to include archaeological information that will help coordinate actions between different offices of the municipality and relevant members of the public, while also raising awareness and facilitating the application of protective measures when needed. Now, some of the tools and concepts that were developed and tested with the help of the INPC and included in the ordinance draft are being applied by the IMP and planification offices 
in Quito to help protect the archaeological heritage of the city until the draft of the legislation is presented.

With regard to community incorporation in this process, it is important to mention that public presentation, public forums with the area's inhabitants, and visits to sensible areas are constantly undertaken. The objective of this outreach is to promote awareness of the importance of the archaeological remains to the identity of the city. Until now, most of this strategy is linked to the ongoing projects carried out by the IMP. In this context, the development tool will help to protect but also make more visiblethe presence of archaeological remains. This is important because, even if the tool can help in an administrative way to ensure the protection of archaeological heritage, the engagement of the involved parties and the community is fundamental to make it possible.

Finally, it is worth highlighting that all of the identified and delimited sites during this project have entered into the research planification of the IMP in order to conduct investigations and further promote their protection. Constant involvement of the landowners and local communities is crucial in the development of strategies to protect the sites and divulgate information about research results and general archaeological concepts and knowledge.

\section{References}

Aguilera M. 2007. Rescate arqueológico. Terminal complemento Oeste, Nuevo Aeropuerto Internacional de Quito (NAIQ) Informe. Quito: CORPAQ.

Aguilera M. 2008/2009. Rescate arqueológico Zona Franca CORPAQ 1B, Sector 1, Nuevo Aeropuerto Internacional de Quito. Informe. Quito: CORPAQ.

Aguilera M. 2009. Investigación arqueológica: Prospección, Rescate y Monitoreo en el Nuevo Aeropuerto Internacional de Quito (NAIQ, Z3B1-075). Informe. Quito: CORPAQ.

BRAY T.L. 2003. Los efectos del imperialismo incaico en la frontera norte: Una investigación arqueológica en la sierra septentrional del Ecuador. Quito: Abya - Yala.

BuYs J. 1987. Proyecto de prospección arqueológica de la Hoya de Guayllabamba. Convenio bilateral Ecuador - Belgica. Quito: INPC.

BUYs J. 1994. Investigación arqueológica en la provincia de Pichincha. Quito: Libri Mundi.

Constantine A. 2013. Rumipamba bajo la sombra del Pichincha. Estudio de complementación de datos actualísticos Parque Arqueológico-Ecológico Rumipamba. Quito: IMP.

Delgado-Espinoza F. 2008. Método y teoría en la arqueología ecuatoriana. In: JARAmillo G.o (Ed.), Memorias del primer seminario internacional de arqueología. Bogotá: UNIANDES.

Domínguez V. 2002. Mapa arqueológico del Distrito Metropolitano de Quito. Bloque Centro. Informe. Quito: FONSAL.

Domínguez V. 2008. Prospección intra-sitio, excavación y monitoreo en el área de Ciudad Bicentenario - Sitio Arqueológico Tajamar Z3B1-017 (lado sur) - Primera parte. Informe. Quito: FONSAL. 
Dominguez V., Chacon R., Mejia F., SAnchez F. \& Ibarra A. 2003. Identificación de Zonas arqueológicas en el área Urbana de Quito. Informe. Quito: INPC.

Doyon L. 1988. Tumbas de la nobleza de la Florida. In: CRUZ I. (Ed.) Quito antes de Benalcázar. Centro Cultural Artes, Serie Monográfica No 1 Año 1, 51-66. Quito: Casa de La Cultura Ecuatoriana.

ECHEverria J. 2009. La Arqueología de Contrato en Ecuador. Breves reflexiones. Revista de Arqueología Americana, (27): 37-48.

ECHEverría J 1977. Contribución al conocimiento arqueológico de la provincia de Pichincha. Sitios de Chilibulo y Chillogallo. Estudios arqueológicos. 181-225. Quito: PUCE.

GNECCO C. \& SCHMIDT A. 2015. On Contract Archaeology. Internationa Journal of Historical Archaeology, 19: 687-698. https://doi.org/10.1007/s10761-015-0305-6

Instituto Colombiano de Antropología e Historia. 2010. Régimen Legal y Lineamientos técnicos de los programas de Arqueología Preventiva en Colombia. Bogotá: ICANH.

Instituto Metropolitano de Patrimonio. 2020. Términos de Referencia del Proyecto: Delimitación de áreas arqueológicas del Bloque Quito, Cod. CD-MDMQIMP-10-2020. Quito: IMP

Instituto Nacional de Patrimonio Cultural. 2020. Propuesta: Protocolo para la delimitación de polígonos de protección arqueológica y polígonos de sensibilidad arqueológica. Quito: INPC.

JijÓN Y CAAMAÑo J. 1952. Antropología prehispánica del Ecuador. Quito: La Prensa Católica. JIJÓN Y CAAMAÑO J \& LARREA C.M. 1918. Un cementerio incásico en Quito y notas sobre los Incas en el Ecuador. Boletín de la sociedad Jurídico - Literaria XX: 159-260.

Ley Orgánica de Cultura. SAN-2016-2272. Boletín del Registro oficial, año IV, N.913, Sexto Suplemento. 1-35.

LipPI R. 2004. Tropical Forest Archaeology in Western Pichincha, Ecuador. In: QuILTER J. (ed.) Case Studies in Archaeology. Thomson/Wadsworth: Belmont CA.

LONDOÑo W. 2016. Arqueología de contrato y nuevos contratos arqueológicos. Janwa Pana, 15: 117-128.

Matsuda A. \& Okamura K. 2011. Introduction: New Perspectives in Global Public Archaeology. In: Matsuda A. \& Okamura K. (Eds.) New Perspectives in Global Public Archaeology. London: Springer.

MCGimsey C.R. 1972. Public Archeology. New York: Seminar Press.

Ministerio da Cultura and Istituto do Patrimonio Historico e Artistico Nacional. 2015. Instrução Normativa n.001 de 25 de Março de 2015. Brasilia: IPHAN.

Montalvo-Puente C.E., Dyrdahl E., Cantisani M., De Fabritis L. \& Vinci S. 2020. La implementación del SIG de excavación: el caso de estudio de los sitios Las Orquídeas y Huataviro (Imbabura, Ecuador). Arqueología Iberoamericana, 46: 34-44.

MonTAlvo-PuENTE C.E. 2020. La prospección arqueológica basada en imágenes satelitales: el caso de la zona norte del país caranqui (Imbabura, Ecuador). Arqueología Iberoamericana, 45: 35-42.

Montalvo-Puente C.E. \& Dyrdahl E. 2017. Combining digital and traditional survey techniques: A case study from Northern Ecuador integrating remote sensing and pedestrian survey. Conferencia. European Archaeological Association Annual Meeting, ses. 404. 
Montalvo-Puente C.E., Rivera-Sañay V., Solines-Moreno S., Riofrío M.G. \& Granja G. 2021. Delimitación de Áreas Arqueológicas del Bloque Quito. Informe. Quito: IMP.

PORRAS P. 1982. Arqueología de Quito I Fase Cotocollao. Centro de investigaciones arqueológicas. Quito: PUCE.

Posada-Restrepo W.A. \& DuQue-TANGarife C.C. 2018. Modelamiento espacial para la gestión del patrimonio arqueológico. Un estudio de caso en el departamento de Caldas, Colombia. NOVUM 8, II: 24-42.

RiCHARDSON L. \& ALmANSA-SÁNCHEZ J. 2015. Do you even know what public archaeology is? Trends, theory, practice, ethics. World Archaeology, 47:2, 194-211, DOI: 10.1080/00438243.2015.1017599

SÁNCHEZ A. 2020. Informe Final Monitoreo Arqueológico de la Línea 1 del Metro de Quito. Informe. Quito: INPC.

TAmayo F. 2005. Mapa arqueológico del Distrito Metropolitano de Quito. Bloque SE Píntag, Segunda Etapa. Informe. Quito: FONSAL.

TANTAlÈn H. \& GonZALEZ A. 2017. La Arqueología de contrato en el Perú: Surgimiento, Caracterización y perspectivas. In: PELLINI J.R. (Ed.) Arqueología comercial: Dinero, alienación y anestesia. Madrid: JAS arqueología.

UHLE M. 1926. Excavaciones arqueológicas en la región de Cumbayá. Anales de la universidad Central vol. XXXVII,257, 5-37.

UGALDE M.F. 2019. Rancho Bajo: primeras evidencias del precerámico terminal en Quito. Arqueología Iberoamericana, 42:14 - 27.

UgALdE M.F. \& DYRDAHL E. (2020). Excavación arqueológica en el sitio Tagshima. Informe. Quito: IMP.

VALDEZ F. 2010. La investigación arqueológica en el Ecuador: reflexiones para un debate. Revista del Patrimonio Cultural del Ecuador 2: 6-23.

Villalba M. 2004. Mapa arqueológico del Distrito Metropolitano de Quito. Bloque SE Píntag, Primera Etapa. Informe. Quito: FONSAL.

VILLALBA M. 1996. Informe de prospección proyecto Valle de Quito. Informe. Quito: Banco Central del Ecuador.

VillalbA M. 1988. Cotocollao: una aldea formativa del valle de Quito. Miscelánea Antropológica Ecuatoriana. Serie Monográfica, No. 2. Quito: Banco Central del Ecuador. 
102 CARLOS MONTALVO ET AL. 